\title{
CUTICLE-DEGRADING PROTEASES PRODUCED BY THE ENTOMOPATHOGENIC FUNGUS BEAUVERIA BASSIANA IN THE PRESENCE OF COFFEE BERRY BORER CUTICLE
}

\author{
B.A. Dias' ${ }^{1}$; P.M.O.J. Neves²; L. Furlaneto-Maia ${ }^{3}$; M.C. Furlaneto ${ }^{\text {* }}$
}

${ }^{1}$ Centro de Ciências Biológicas, Universidade Estadual de Londrina, Londrina, PR, Brasil; ${ }^{2}$ Centro de Ciências Agrárias, Universidade Estadual de Londrina, Londrina, PR, Brasil; ${ }^{3}$ Universidade Tecnológica Federal do Paraná, Londrina, PR, Brasil.

Submitted: July 12, 2007; Returned to authors for corrections: November 26, 2007; Approved: February 13, 2008.

\begin{abstract}
A Brazilian isolate of Beauveria bassiana (CG425) that shows high virulence against the coffee berry borer (CBB) was examined for the production of subtilisin-like ( $\operatorname{Pr} 1)$ and trypsin-like ( $\operatorname{Pr} 2)$ cuticle-degrading proteases. Fungal growth was either in nitrate-medium or in CBB cuticle-containing medium under both buffered and unbuffered conditions. In unbuffered medium supplemented with cuticle, the $\mathrm{pH}$ of cultures dropped and $\operatorname{Pr} 1$ and $\operatorname{Pr} 2$ activities were detected in high amounts only at a $\mathrm{pH}$ of 5.5 or higher. In buffered cultures, $\operatorname{Pr} 1$ and $\operatorname{Pr} 2$ activities were higher in medium supplemented with cuticle compared to activities with nitrate-medium. The $\operatorname{Pr} 1$ and $\operatorname{Pr} 2$ activities detected were mostly in the culture supernatant. These data suggest that $\operatorname{Pr} 1$ and $\operatorname{Pr} 2$ proteases produced by strain CG425 are induced by components of CBB cuticle, and that the culture $\mathrm{pH}$ influences the expression of these proteases, indicating the occurrence of an efficient mechanism of protein secretion in this fungus. The results obtained in this study extend the knowledge about protease production in B. bassiana CG425, opening new avenues for studying the role of secreted proteases in virulence against the coffee berry borer during the infection process.
\end{abstract}

Key-words: subtilisin-like protease, trypsin-like protease, Hypothenemus hampei

\section{INTRODUCTION}

The coffee berry borer (CBB) Hypothenemus hampei (Ferrari) (Coleoptera: Curculionidae) is considered the most important coffee pest throughout the world. It is present in most coffee producing countries (19). The biology of CBB presents formidable challenges for the implementation of pest management programs. CBB lives the greatest part of its life cycle inside the coffee berry, which involves egg laying followed by the emergence of adult females from the berry. The control of CBB still depends largely on the application of synthetic insecticides which show limitations due to potential adverse effects to human health and the environment, and the development of pesticide resistance by the coffee berry borer to endosulfan (12). Due to its cryptic lifestyle, the use of biocontrol agents could be an effective alternative to chemical control.
The entomopathogenic fungus Beauveria bassiana (Balsamo) Vuillemin is the most prevalent fungus attacking CBB populations in African countries where this insect originated, as well as in those countries where the borer has spread, including Brazil $(1,7,32)$. Currently, commercial products based on $B$. bassiana are available for CBB control $(8,23)$. Recently, it was shown that the Brazilian strain CG425 of B. bassiana was the most virulent against the coffee berry borer among 60 strains tested (21). Furthermore, this strain showed compatibility with chemical insecticides used in the coffee crop, allowing the development of an integrated pest management program strategy for the crop with reduction in the amount of insecticides applied (21). This fungal strain also presented high mortality against the grasshopper Rhammatocerus schistocercoides (20) which is a serious pest of crops and native pastures in Central Brazil.

Entomopathogenic fungi exhibit many attributes that determine virulence toward their hosts, including the production

*Corresponding Author. Mailing address: Departamento de Microbiologia, Centro de Ciências Biológicas, UEL. P.O. Box 6001, 86051-990 Londrina -PR, Brasil. E-mail: furlaneto@uel.br 
of degradative enzymes. Fungal proteases are believed to play an important role in cuticle penetration (24). The best known determinant of fungal entomopathogenicity is based on subtilisinlike serine protease (designated Pr1) of Metarhizium anisopliae, where its role in host invasion has been clearly demonstrated (26). This enzyme is adapted to extensively degrade insect cuticular protein (25) and has been ultrastructurally located in the host cuticle during the early stages of penetration (13). A trypsin-like enzyme $(\operatorname{Pr} 2)$ belonging to the serine protease group also occurs during the early stages of cuticle colonisation suggesting that it has some role in degrading extracellular proteins complementary to that of $\operatorname{Pr} 1$ (29).

A Pr1 protease from B. bassiana also appears to be a virulence factor given its ability to degrade insect cuticle (6) and considering that a protease-defective mutant was found to have decreased virulence against the migratory grasshopper Melanoplus sanguinipes (5). Gupta et al. (15) found that a high level of Pr1-like proteases produced by B. bassiana appeared to be related to early onset of mortality in the larvae of the wax moth (G. mellonella). According to these authors, trypsin-like proteases did not show a discernible trend. Furthermore, the Pr1 gene from B. bassiana which resembles the M. anisopliae $\operatorname{Pr} 1$ was cloned and sequenced (18), indicating that similar proteases may be widespread among entomopathogenic fungi.

The synthesis of extracellular B. bassiana $\operatorname{Pr} 1$ is controlled by a multiple regulatory circuit in which certain carbon sources together with a nitrogen source repress its synthesis. Its is also controlled by the levels of N-acetyl-D- glucosamine in the culture medium (3,4, respectively). Gupta et al. (14) showed that the production of $\operatorname{Pr} 1$ and $\operatorname{Pr} 2$ proteases is enhanced when $B$. bassiana is grown on insect cuticle. Campos et al. (9) described that tick cuticle also induces $\operatorname{Pr} 1$ production by $B$. bassiana and that the addition of the amino acid alanine to the culture medium repressed Pr1 secretion. Recently, Ito et al. (16) showed that a Brazilian strain of $B$. bassiana reactivated on CBB produced proteases in medium containing glucose and yeast extract. According to these authors B. bassiana produced $80 \%$ of the total of the protease activity in $48 \mathrm{~h}$ being the maximum activity on the $5^{\text {th }}$ culture day.

In this study, we examined for the first time the production of $\operatorname{Pr} 1$ and $\operatorname{Pr} 2$ proteases by B. bassiana in the presence of $H$. hampei cuticle either in unbuffered or in buffered cultures, extending the knowledge about protease production by this fungus.

\section{MATERIALS AND METHODS}

\section{Organism}

Beauveria bassiana $\mathrm{CG} 425$ was obtained as a liquid nitrogenstored stock culture from Cenargen/Embrapa-Brazil collection of entomopathogenic fungi, Brasília-DF.

\section{Enzyme secretion on solid media}

Protease activity was determined by the ability to produce zones of clearing in agar mineral medium (MM)(22) lacking nitrogen source amended with either gelatin or casein at $0.2 \%$ $(\mathrm{w} / \mathrm{v})$ at $\mathrm{pH} 6.8$ and 8.5. Spores were point-inoculated onto agar surfaces and incubated at $28^{\circ} \mathrm{C}$ for up to 7 days. Activities were calculated as the ratio of diameter of the clear zone plus colony to that of the colony.

\section{Culture conditions}

Conidia were obtained by harvesting sporulated cultures grown on agar plates composed of mineral medium (22) containing nitrate as nitrogen source. For enzyme production, conidia were added to $20 \mathrm{ml}$ of liquid $\mathrm{MM}$ and $\mathrm{MM}+$ cuticle at a concentration of $1 \times 10^{7} \mathrm{ml}^{-1}$ and grown in submerged culture ( $180 \mathrm{rpm}$ ) at $28^{\circ} \mathrm{C}$ for up to $168 \mathrm{~h}$. These media were left unbuffered (initial $\mathrm{pH}$ 6.8). The MM+cuticle medium corresponded to MM lacking nitrogen source amended with $0.5 \%(\mathrm{w} / \mathrm{v})$ insect cuticle prepared from adult Hypothenemus hampei using an aqueous solution of $1 \%(\mathrm{w} / \mathrm{v})$ potassium tetraborate. The cuticle extract was added to previously sterilised $\left(121^{\circ} \mathrm{C}\right.$ for $\left.15 \mathrm{~min}\right) \mathrm{MM}$ lacking nitrogen source and autoclaved for $5 \mathrm{~min}$ at $115^{\circ} \mathrm{C}$.

In another set of induction experiments, both $\mathrm{MM}$ and $\mathrm{MM}+$ cuticle were buffered using a universal buffer $(100 \mathrm{mmol}$ $\mathrm{l}^{-1}$ citric acid, $100 \mathrm{mmol} \mathrm{l}^{-1}$ boric acid and $100 \mathrm{mmoll}^{-1} \mathrm{KH}_{2} \mathrm{PO}_{4}$ ), $\mathrm{pH}$ 8.0.

All experiments were repeated three times, and the results represent mean values \pm standard error of the mean (SD).

\section{Preparation of enzyme fractions}

Following growth, mycelium was harvested by centrifugation at $8000 \mathrm{~g}$ for $15 \mathrm{~min}$ and washed in ice-cold $25 \mathrm{mmol} \mathrm{l}^{-1}$ Trissodium phosphate buffer, $\mathrm{pH}$ 6.7. Weighed mycelium was ground to a fine powder in liquid nitrogen, resuspended in lysis

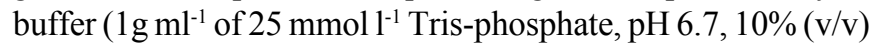
glycerol and $1 \mathrm{mmol}^{-1}$ EDTA) and centrifuged at $12000 \mathrm{~g}$ for $15 \mathrm{~min}$. The supernatant recovered represented the intracellular (cell bound) soluble fraction. Culture filtrates were stored at $20^{\circ} \mathrm{C}$ and used as the extracellular secreted fraction. Both fractions were assayed for protease activity.

\section{Enzyme assays}

In this paper, subtilisin-like activity and trypsin-like activity of $B$. bassiana are referred to as $\operatorname{Pr} 1$ and $\operatorname{Pr} 2$, respectively. Pr1 and $\operatorname{Pr} 2$ activities were assayed using succinyl-(alanine) ${ }_{2}$-prolinephenylalanine- $p$-nitroanilide and benzoyl-phenylalanine-valinearginine- $p$-nitroanilide as substrates, respectively $(25,33)$. Each assay consisted of $0.05 \mathrm{ml}$ substrate $\left(1 \mathrm{mmol}^{-1}\right), 0.85 \mathrm{ml} 15 \mathrm{mmol}$ $\mathrm{I}^{-1}$ Tris- $\mathrm{HCl}$ buffer ( $\mathrm{pH} 8.5$ ) and $0.1 \mathrm{ml}$ crude enzyme. The mixture was incubated for $1 \mathrm{~h}$ at $28^{\circ} \mathrm{C}$ and the reaction was terminated by adding $0.25 \mathrm{ml}$ of $30 \%$ acetic acid and left to stand for $15 \mathrm{~min}$ in ice, after which samples were centrifuged at $1250 \mathrm{~g}$ for $5 \mathrm{~min}$ at 
$4^{\circ} \mathrm{C}$. The supernatants were read at $410 \mathrm{~nm}$. Activities were expressed as nanomoles nitroanilide (NA) released per milliliter per min (28). Assays were performed in duplicate for each sample.

\section{RESULTS}

In this study, we determined the production of $\operatorname{Pr} 1$ and $\operatorname{Pr} 2$ proteases by $B$. bassiana CG425 in liquid culture, either in the presence or absence of coffee berry borer cuticle (H. hampei). In unbuffered medium containing nitrate as sole nitrogen source, the culture $\mathrm{pH}$ values ranged from 6.0 to 7.9 at different incubation times and the levels of $\operatorname{Pr} 1$ and $\operatorname{Pr} 2$ proteases were high at all incubation periods analysed (Tables 1 and 2). The $\mathrm{pH}$ of cultures dropped below 5.0 in unbuffered medium supplemented with cuticle, and $\operatorname{Pr} 1$ and $\operatorname{Pr} 2$ activities were detected in highest amounts in the late stage of growth when the culture $\mathrm{pH}$ reached 5.5 (Tables 1 and 2).

In buffered cultures ( $\mathrm{pH} 8.0$ in culture supernatants), Pr1like proteases were also detected in the absence of $H$. hampei cuticle. However, in contrast to that observed in unbuffered cultures at its highest level, Pr1 activity was approximately 3fold higher in mineral medium containing ground cuticle than in mineral medium containing nitrate as sole nitrogen source (Table1). In the former, protease production was high at $72 \mathrm{~h}$ and remained constant up to $168 \mathrm{~h}$. Increased protease production was observed in nitrate-medium starting at $120 \mathrm{~h}$. Similarly, Pr2-like activity was higher in medium supplemented with cuticle at all incubation times compared to activities on non-cuticular substrate (Table 2).

These data suggest that $\operatorname{Pr} 1$ and $\operatorname{Pr} 2$ proteases produced by strain CG425 are induced by protein components of coffee berry borer cuticle, and that the culture $\mathrm{pH}$ influences the expression of these protease types.

We also analysed protease activity on agar plates containing mineral medium lacking nitrogen source amended with either gelatin or casein. Protease activity in gelatin-containing medium was $3.56 \pm 0.22$ and $3.25 \pm 1.08$ in cultures at $\mathrm{pH} 6.8$ and 8.5, respectively. In casein-containing medium, protease activity was $1.87 \pm 0.31$ and $2.2 \pm 0.08$ in cultures at 6.8 and 8.5 , respectively. Unlike in liquid cultures, the plate clearing assay for protease determination did not reveal the effect of culture $\mathrm{pH}$ on protease activity.

As shown in Tables 1 and 2, Pr1 activities were higher than $\operatorname{Pr} 2$ activities in buffered media containing cuticle, although both types of proteases were detected after $48 \mathrm{~h}$ of growth, suggesting that these types of proteases are not coordinately expressed in this fungal strain.

We also analysed the distribution of Pr1 and Pr2 in both secreted and cell bound fractions after growth in unbuffered media, to increase our knowledge about protease secretion by this fungus. The Prl activities detected were mostly in the culture supernatant in either mineral medium or cuticle-containing medium. The percentage of Pr1 protease in the supernatant was $98-100 \%$ in mineral medium and $70-82 \%$ in cuticle-containing medium. The predominance of secreted $\operatorname{Pr} 2$ was also observed, even in nitrate-containing medium (up to $99 \%$ ), suggesting the occurrence of an efficient mechanism of protein secretion by this fungus.

\section{DISCUSSION}

Fungal pathogenesis is a complex and multi-factorial phenomenon, with particular virulence factors coming into play at various stages of infection and death. Like most fungal pathogens, $B$. bassiana might use a combination of enzymes to penetrate the cuticle and access the nutrient-rich host haemocoel.

The extracellular protease of $B$. bassiana has been implicated as a component of the insect infection process (5), and in this study we report on the regulation of $\operatorname{Pr} 1$ and $\operatorname{Pr} 2$ protease production by the isolate CG425 in liquid culture, as a function of nitrogen source and $\mathrm{pH}$.

The detection of high levels of Pr1 and Pr2 proteases only in the late stages of growth in unbuffered medium containing $H$. hampei suggests that low culture $\mathrm{pH}$ had an effect on protease levels. In an earlier study, Bidochka and Khachatourians (3) described that an extracellular protease produced by $B$. bassiana in gelatin-containing medium was unstable at $\mathrm{pH}$ levels below 5. The decrease in $\mathrm{pH}$ in $B$. bassiana culture supernatants may have been due to the accumulation of metabolic acids such as oxalic acid in the medium as reported by Cordon and Schwartz (10). Our finding of a drop in $\mathrm{pH}$ only in medium supplemented with coffee berry borer cuticle needs further investigation, particularly as it relates to fungal utilisation of this substrate and to the process of insect infection.

In experiments where the $\mathrm{pH}$ of the culture supernatant was kept at 8.0, the addition of $H$. hampei cuticle to the medium had a positive effect on both types of protease ( $\operatorname{Pr} 1$ and $\operatorname{Pr} 2)$ activity. In the presence of cuticle, the production of these proteases seemed to be induced when the external $\mathrm{pH}$ is alkaline (Tables 1 and 2). These data suggest that both proteases are induced by specific components of the cuticle, and that their detection occurs at $\mathrm{pH}$ levels close to its $\mathrm{pH}$ optimum. B. bassiana $\operatorname{Pr} 1$ protease activity is maximum at $\mathrm{pH} 8.5$ (2). St. Leger et al. (28) described that $M$. anisopliae produces extracellular proteases only at the $\mathrm{pH}$ at which they are active. According to these authors, there is evidence for a concerted action of $\mathrm{pH}$ and presence of cuticle on enzyme induction in M. anisopliae. In contrast, a subtilisin-type serine protease produced by Aspergillus niger is expressed at equally high levels at $\mathrm{pH} 3$ and 8 (17). Recently Donatti et al. (11) described that the amino acid methionine seems to play a regulatory role in $\operatorname{Pr} 1$ secretion by $B$. bassiana, since both induction and repression seem to be dependent on the concentration of the amino acid present in 

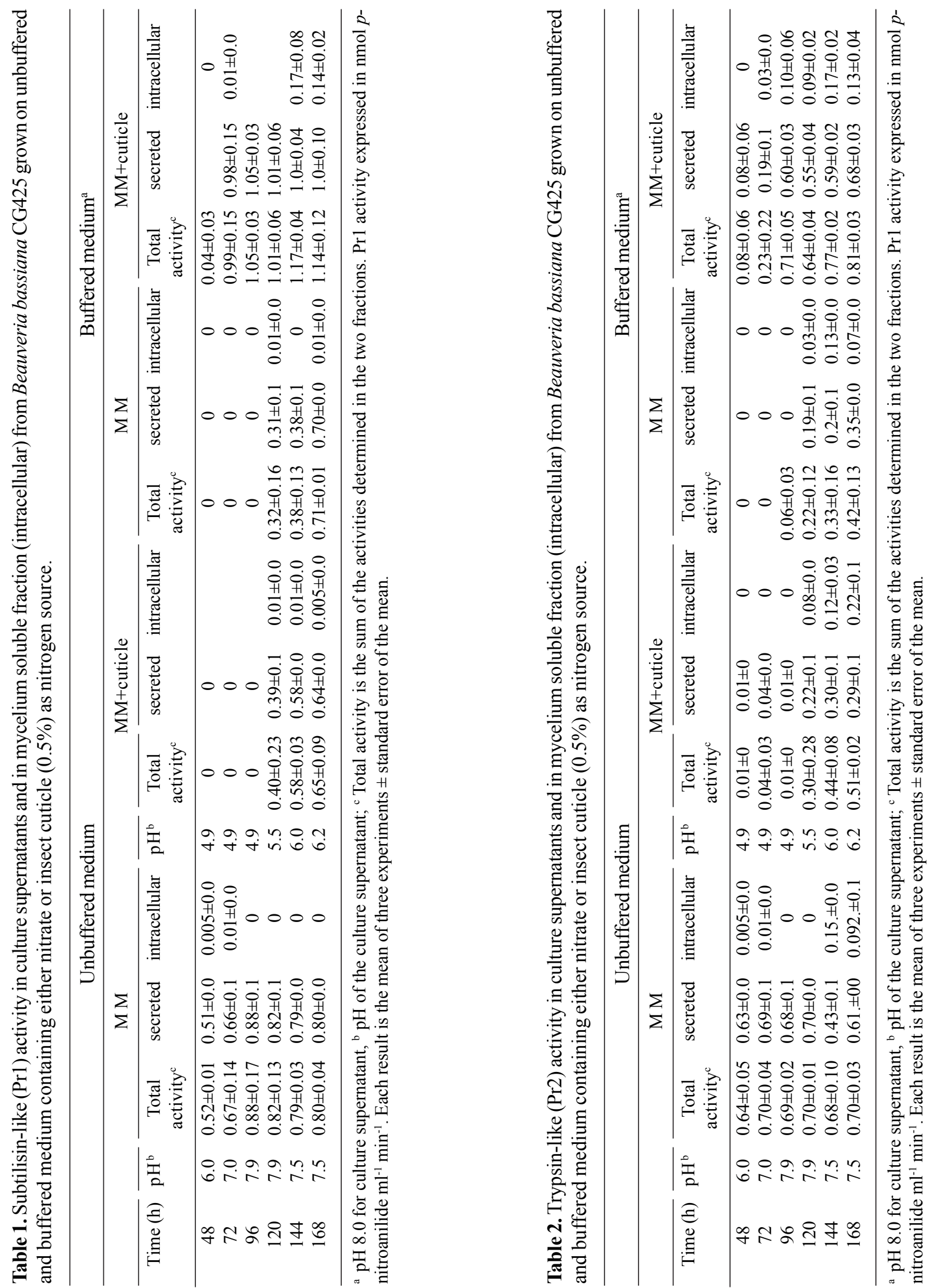
the culture medium. For M. anisopliae it has been suggested that alkalinization by ammonia production is adaptive by facilitating the utilization of proteinaceus substrates. Growing $M$. anisopliae in the presence of low levels of methionine resulted in high levels of ammonia formation (30).

Furthermore, the production of $\operatorname{Pr} 1$ and $\operatorname{Pr} 2$ by strain CG425 in cuticle-containing medium does not seem to be coordinately expressed, since both were detected after $48 \mathrm{~h}$ of growth, similar to that observed for Metarhizium anisopliae var. acridum (31).

In buffered cultures, both protease types were produced, albeit at lower levels, by carbon and nitrogen derepression alone indicating a substantial basal level of Pr1 and Pr2 (Tables 1 and 2). Similar results were obtained by Gupta et al. (14). In contrast, Bidochka and Khachatourians (3) reported that B. bassiana strain GK2016 did not produce protease in the absence of exogenous protein.

The main focus of most studies on cuticle-degrading enzymes produced by entomopathogenic fungi has been on extracellular activities. In this study, we analysed the protease activities in secreted and intracellular fractions. The high percentage of secreted proteases observed for both protease types $(\operatorname{Pr} 1$ and $\operatorname{Pr} 2)$, compared to the intracellular activities, suggests the occurrence of an efficient mechanism of protein secretion in this fungus. Tiago et al. (31) also described a high percentage of secreted proteases from $M$. anisopliae var. acridum in cuticle-containing medium. Enzyme secretion by entomopathogenic fungi may be involved in the degradation of cuticular polymers during pathogenesis, assisting in the penetration of the insect exoskeleton and providing nutrients for fungal growth (13). However, there is evidence suggesting that certain M. anisopliae extracellular enzymes remain, in part, associated with the cell surface, which could be of benefit to the fungus as products of the enzyme action would be more readily absorbed (27).

The study of the regulation of virulence factors in entomopathogenic fungus is of particular importance because pathogenic specialisation may operate by way of regulatory controls that allow their expression. Furthermore, studies of the timing of the production of proteases and other factors in the presence of cuticular substrates could provide information about the role of the accumulated hydrolytic enzymes during pathogenesis. The results presented in this study increase the knowledge about protease production in B. bassiana CG425, opening new avenues for the study of the role of secreted proteases in virulence against the coffee berry borer during the infection process.

\section{ACKNOWLEDGEMENTS}

This work was supported by Conselho Nacional de Desenvolvimento Científico e Tecnológico (CNPq) and Coordenação de Aperfeiçoamento de Pessoal de Nível Superior
(CAPES) -Brazil. The authors thank Dr. Amador Villacorta for providing the coffee borer and Dr. Albert Leyva for reading the manuscript.

\section{RESUMO}

\section{Proteases degradadoras de cutícula produzidas pelo fungo entomopatogênico Beauveria bassiana $\mathrm{em}$ presença de cutícula de broca do café}

O isolado brasileiro de Beauveria bassiana (CG425) que apresenta alta virulência contra a broca do café (CBB) foi analisado quanto à produção de proteases degradadoras de cutícula, tipo-subtilisina $(\operatorname{Pr} 1)$ e tipo-tripsina $(\operatorname{Pr} 2)$. O crescimento fúngico foi realizado em meio contendo nitrato e em meio contendo cutícula da broca em condições de $\mathrm{pH}$ tamponado e não tamponado. Em meio não tamponado, suplementado com cutícula, o pH da cultura caiu e as atividades de Pr1 e Pr2 foram detectadas somente em valores de $\mathrm{pH}$ igual ou superior a 5,5. Em culturas tamponadas, as atividades $\operatorname{Pr} 1$ e $\operatorname{Pr} 2$ foram superiores em meio suplementado com cutícula, comparativamente as atividades em meio contendo nitrato. As atividades $\operatorname{Pr} 1$ e $\operatorname{Pr} 2$ ocorreram predominantemente no sobrenadante de cultivo. Os dados obtidos sugerem que Pr1 e Pr2 produzidas pelo isolado CG425 são induzidas por componentes da cutícula da broca do café (CBB), e que o pH da cultura influencia a expressão destas proteases, indicando a ocorrência de um mecanismo eficiente de secreção por este fungo. Os resultados obtidos neste estudo aumentam o conhecimento a respeito da produção de proteases por $B$. bassiana CG425, abrindo novos caminhos para o estudo do papel de proteases na virulência contra a broca do café durante o processo de infecção.

Palavras chave: protease tipo-subtilisina, protease tipo-tripsina, Hypothenemus hampei

\section{REFERENCES}

1. Benassi, V.L.R.M. (1995). Levantamento dos inimigos naturais da broca do café Hypothenemus hampei (Ferr.) (Coleoptera: Scolytidae) no norte do Espírito Santo. An. Soc. Entomol. Bras., 24, 635-638.

2. Bidochka, M.J.; Khachatourians, G.G. (1987). Purification and properties of an extracellular protease produced by the entomopathogenic fungus Beauveria bassiana. Appl. Environ. Microbiol., 53, 1679-1684.

3. Bidochka, M.J.; Khachatourians, G.G. (1988a). Regulation of extracellular protease in the entomopathogenic fungus Beauveria bassiana. Exp. Mycol., 13, 161-168.

4. Bidochka, M.J.; Khachatourians, G.G. (1988b). N-Acetyl-DGlucosamine-mediated regulation of extracellular protease in the entomopathogenic fungus Beauveria bassiana. Appl. Environ. Microbiol., 54, 2699-2704.

5. Bidochka, M.J.; Khachatourians, G.G. (1990). Identification of Beauveria bassiana extracellular protease as a virulence factor in 
pathogenicity toward the migratory grasshopper, Melanoplus sanguinipes. J. Invertebr. Pathol., 56, 362-370.

6. Bidochka, M.J.; Khachatourians, G.G. (1994). Protein hydrolysis in grasshopper cuticles by entomopathogenic fungal extracellular proteases. J. Invertebr. Pathol., 63, 7-13.

7. Bustillo, A.E.; Cárdenas, R.; Villalba, D.; Benavides, P.; Orozco, J.; Posada, F.J. (1998). Manejo integrado de la broca del café, Hypothenemus hampei (Ferrari) em Colombia. Chinchina, Cenicafé, 134p.

8. Butt, T.M.; Jackson, C.; Magan, N. (2001). Introduction - Fungal Biological Control Agents: Progress, Problems and Potential. In Fungi as Biocontrol Agents: Progress, Problems and Potential. CABI Publishing, New York, USA, p. 1-8.

9. Campos, R.A.; Arruda, W.; Boldo, J.T.; Silva, M.V.; Barros, N.M.; Azevedo, J.L.; Schrank, A.; Vainstein, M.H. (2005). Boophilus microplus infection by Beauveria amorpha and Beauveria bassiana: SEM analysis and regulation of subtilisin-like proteases and chitinases. Curr. Microbiol., 50, 257-261.

10. Cordon, T.C.; Schwartz, J.H. (1962). The fungus Beauveria tenella. Science, 138, 1265-1266.

11. Donatti, A.C.; Furlaneto-Maia, L.; Fungaro, M.H.P.; Furlaneto, M.C. (2008). Production and regulation of cuticle-degrading proteases from Beauveria bassiana in the presence of Rhammatocerus schistocercoides cuticle. Curr. Microbiol., 56, 256-260.

12. ffrench-Constant, R.H.; Steichen, J.C.; Brun, L.O. (1994). A molecular diagnosis for endosulfan insecticide resistance in the coffee berry borer Hypothenemus hampei. Bull. Entomol. Res., 84, 11-16.

13. Goettel, M.S.; St. Leger, R.J.; Rizzo, N.W.; Staples, R.C.; Roberts, D.W. (1989). Ultrastructural localization of a cuticle degrading protease produced by the entomopathogenic fungus, Metarhizium anisopliae during penetration of host cuticle. J. Gen. Microbiol., 135, 2223-2239.

14. Gupta, S.C.; Leathers, T.D.; El-Sayed, G.N.; Ignoffo, C.M. (1992). Insect cuticle-degrading enzymes from the entomogenous fungus Beauveria bassiana. Exp. Mycol., 16, 132-137.

15. Gupta, S.C.; Leathers, T.D.; El-Sayed, G.N.; Ignoffo, C.M. (1994). Relationships among enzyme activities and virulence parameters in Beauveria basiana infections of Galleria mellonella and Trichoplusia ni. J. Invertebr. Pathol., 64, 13-17.

16. Ito, E.T.; Varéa-Pereira, G.; Mitagui, D.T.; Pinotti, M.H.P.; Neves, P.M.O.J. (2007). Production of extracellular protease by a Brazilian strain of Beauveria bassiana reactivated on coffee berry borer, Hypothenemus hampei. Braz. Arch. Biol. Technol., 50, 217-223.

17. Jarai, G. and Buxton, F. (1994). Nitrogen, carbon, and pH regulation of extracellular acidic proteases of Aspergillus niger. Curr. Genet., $26,238-244$.

18. Joshi, L.; St. Leger, R.J.; Bidochka, M.J. (1995). Cloning of a cuticledegrading protease from the entomopathogenic fungus, Beauveria bassiana. FEMS Microbiol. Lett., 125, 211-218.

19. Le Pelley, R.H. (1968). Pests of coffee. Longmans, Green and Co. Ltd., London, 590p.
20. Magalhães, B.P.; Goettel, M.S.; Frazão, H.S. (2000). Sporulation of Metarhizium anisoplaie var. acridum and Beauveria bassiana on Rhammatocerus schistocercoides under humid and dry conditions. Braz. J. Microbiol., 31, 162-164.

21. Oliveira, C.N.; Neves, P.M.O.J.; Kawazoe, L.S. (2003). Compatibility between the entomopathogenic fungus Beauveria bassiana and insecticides used in coffee plantations. Sci. Agr., 60, 663-667.

22. Pontecorvo, G.; Roper, J.A.; Hemons, L.M.; MacDonald, K.D.; Bufton, AW.J. (1953). The genetics of Aspergillus nidulans. Adv. Genet., 5, 141-238.

23. Reithinger, R.; Davies, C.R.; Cadena, H.; Alexander, B. (1997). Evaluation of the fungus Beauveria bassiana as a potential biological control agent against phlebotomine sand flies in Colombian coffee plantations. J. Invertebr. Pathol., 70, 131-135.

24. St Leger, R.J. (1995). The role of cuticle-degrading proteases in fungal pathogenesis of insects. Can. J. Bot., 73, S1119-S1125 (Suppl. 1).

25. St. Leger, R.J.; Charnley, A.K.; Cooper, R.M. (1987). Characterization of cuticle degrading proteases produced by the entomopathogen Metarhizium anisopliae. Arch. Biochem. Biophys., 253, 221-232.

26. St. Leger, R.J.; Durrands, P.K.; Charnley, A.K.; Cooper, R.M. (1988). Role of extracellular chymoelastase in the virulence of Metarhizium anisopliae for Manduca sexta. J. Invertebr. Pathol., 52, 285-293.

27. St Leger, R.J.; Goettel, M.; Roberts, D.W.; Staples, R.C. (1991). Prepenetration events during infection of host cuticle by Metarhizium anisopliae. J. Invertebr. Pathol., 58, 168-179.

28. St Leger, R.J.; Joshi, L.; Bidochka, M.J.; Roberts, D.W. (1998). Ambient $\mathrm{pH}$ is a major determinant in the expression of cuticledegrading enzymes and hydrophobin by Metarhizium anisopliae. Appl. Environ. Microbiol., 64, 709-713.

29. St Leger, R.J.; Joshi, L.; Bidochka, M.J.; Rizzo, N.W.; Roberts, D.W. (1996). Biochemical characterization and ultrastructural localization of two extracellular trypsins produced by Metarhizium anisopliae in infected insect cuticles. Appl. Environ. Microbiol., 62, 1257-1264.

30. St Leger, R.J.; Nelson, J.O.; Screeen, S.E. (1999). The entomopathogenic fungus Metarhizium anisopliae alters ambient $\mathrm{pH}$, allowing extracellular protease production and activity. Microbiology, 145, 2691-2699.

31. Tiago, P.V.; Fungaro, M.H.P.; Furlaneto, M.C. (2002). Cuticledegrading proteases from the entomopathogen Metarhizium flavoviride and their distribution in secreted and intracellular fractions. Lett. Appl. Microbiol., 34, 91-94.

32. Villacorta, A. (1984). Ocorrência de Beauveria sp infectando a brocado-café, Hypothenemus hampei (Ferrari, 1867) (Coleoptera: Scolytidae) em lavouras no Estado do Paraná. An. Soc. Entomol. Bras., 13, 177-178.

33. Urtz, B.E.; Rice, W.C. (2000). Purification and characterization of a novel extracellular protease from Beauveria bassiana. Mycol. Res., 104: 180-186. 